\title{
REVIVAL OF UKRAINIAN BLACKSMITHING: ART PRACTICES AND EDUCATION DURING THE 1970S-2010S
}

\author{
Svitlana Rohotchenko \\ Modern Art Research Institute of the National Academy of Arts of Ukraine, Ukraine
}

\begin{abstract}
The article is aimed at making an outline of the revival process experienced by professional Ukrainian blacksmithing art, development of which resumed in the 1970s, after an imposed pause that had lasted for over half a century. The facts from the history of development and further evolution of blacksmithing are publicized, as well as the reasons that caused almost complete distinction of traditional blacksmithing handicraft and professional blacksmithing art as a result of suppression by the Soviet power. The objective of the research is a real-time coverage of the stages of revival of blacksmithing craft, art, and education. Extermination of the traditional blacksmithing education that existed in Ukraine since the 16th century and up till 1917 took its toll. Young blacksmiths were trained in the forges where they worked as assistants. The first departments of artistic blacksmithing were established in the colleges, technical schools, institutes, and academies only in the late 1980s. Lack of specialized education was a drawback for Ukrainian blacksmithing comparing to the European states where there was no gap in training practice. In the article, the most well-known modern Ukrainian blacksmithing educational institutions are analyzed on the basis of historical method, chronological and cultural approaches.
\end{abstract}

Keywords: blacksmithing, craft, fine art, innovations, traditions.

\section{Introduction}

At the present time, the issues of Ukrainian blacksmithing art and craft are extensively studied in the context of art history, culturology, pedagogy by both Ukrainian and foreign scholars. However, it may be stated that comparing to the research works covering other sectors of visual arts-fine art, graphics, sculpture, architecture, decorative and applied arts - and pedagogy, the number of such publications is relatively small.

Thus, the main aim of the article is to give an outline of the revival process of Ukrainian blacksmithing art with the special focus on blacksmithing education. The material in this paper would allow making art historical, historical, economic, and cultural conclusions about the staged development of the blacksmithing art in Kyiv during the 1970s-2020s - the period that was labeled a "Renaissance" of Ukrainian blacksmithing. (The period of the late 19th and the turn of the 20th 
century is considered the initial era of rapid development of blacksmithing art and craft linked to the intensive urban construction.) Therefore, another aim of the article is to present a periodization of blacksmithing art in Ukraine that runs contrary to some scholars' opinions and to determine the main consequent stages of revival of blacksmithing art and education in Ukraine.

The final and ultimate aim of the research is to argue that revival of blacksmithing art and education was one of the ways of regaining and rediscovering their national identity for Ukrainians.

\section{Literature Review}

Sporadic works that directly or indirectly cover the development of blacksmithing and jewelry making crafts, as well as the art of blacksmithing since the Middle Ages and up till now are chosen as a basis for this research. While the number of studies on the Ukrainian blacksmithing school is scant, there are hardly any publications that address blacksmithing education.

Among the scholars, there exists a range of opinions, sometimes contrasting, regarding the role and meaning of decorative and applied arts within the broader framework of general revival of Ukrainian culture in the post-Soviet time. For instance, according to Lilia Pasichnyk (2017), Kateryna Horchar (2013), and Serhiy Luts (2013), extermination of the blacksmithing art tradition did not significantly affect the general course of cultural development of the state. I, on the contrary, support Joseph Hofmarcher (2019) in his opinion that blacksmithing culture can bring a huge potential to society.

Lesya Smyrna (2017) first stated that turning to applied arts in general and blacksmithing in particular was one of the ways of regaining their national identity for Ukrainian artists during the late Soviet era.

\section{Methodology}

Methodology of the study includes historical, chronological, cultural approaches. Studying archival sources and analyzing the artworks completed between 1970 and 2020 allowed to form a broad socio-cultural context and present the real picture of the "Renaissance" of Ukrainian blacksmithing art. Also, a widely used method of interview with the participants of art process enables making a detailed account of the establishment and development of the departments of ironwork and artistic blacksmithing in the contemporary Ukrainian secondary and higher educational institutions. 
SOCIETY. INTEGRATION. EDUCATION

Proceedings of the International Scientific Conference. Volume IV, May $28^{\text {th }}-29^{\text {th }}$, 2021. 680-692

\section{Results of the Research}

Contrary to some established views, I consider the 1970s to be not the initial period of contemporary Ukrainian blacksmithing art, but only a stage in a largerscale cultural process. I argue that the first period of Ukrainian blacksmithing art and craft started as early as the 15th century and ended in the first half of the 19th century. The second stage unfolded from the mid-19th century and up to 1917. Forcible extermination of blacksmithing art marks the third stage-the gap between 1917 and 1970. The fourth stage of rapid blacksmithing development started in the 1970s and ended in the 2000s. The fifth and last stage of stagnation and certain decline has lasted since the early 21st century and up to the present time.

Naming the 1970s a stage and not the starting point in evolution of Ukrainian blacksmithing art enables to identify and see the elements of traditional Ukrainian ornaments and symbols. If perceived out of the context of tradition, these elements could not be correctly interpreted and evaluated. Moreover, asserting a continuity of blacksmithing tradition reinforces the rediscovery of Ukrainian national identity that is ongoing and often painful process.

As the result of the research, it was determined that the main centers for blacksmithing education in contemporary Ukraine are Kyiv, Lviv, Uzhhorod, and Ivano-Frankivsk.

\section{Discussion}

The process of studying the issues of revival and development of Ukrainian blacksmithing art proved that in the period since the 1917 and up to the 1970s not only traditional profession was exterminated, but also the very school of blacksmithing mastery and tradition of blacksmithing education that, in essence, is a prolonged direct personal communication of master and disciple. While development of blacksmithing, one of the most significant applied arts, was put on a long pause, some young researchers, including Lilia Pasichnyk (2017), Kateryna Horchar (2013), and Serhiy Luts (2013), still controversially consider that this inflicted little damage to the general development of Ukrainian culture.

It could be argued that revival of blacksmithing art in Ukraine went a unique and fundamentally original path. Lesya Smyrna in her monographic study $A$ Century of Nonconformism in Ukrainian Visual Art (Smyrna, 2017) convincingly states that blacksmithing was one of the ways to regain national identity for Ukrainians.

Yet, none of the Ukrainian or foreign researchers pointed out that turning to blacksmithing as an art during the 1970s-1990s-the period of mature socialist realism-was a manifestation of dissent and nonconformity for an artist in Ukraine. Also, none of the scholars acknowledged that development of blacksmithing in 
Kyiv region was prompted by return of professional artists blacksmiths (and not craftsmen) to the forges. In contrast to Kyiv region, in other areas of Ukraine certain level blacksmithing craft was preserved and professional skills were passed to students, nevertheless never reaching the level of artistic creativity.

As for the role of art education in the process of rediscovering the core of national identity, Tetiana Zuziak (2017) argues that motivational and psychological components of the educational process (i.e. motivation of the educator) correspond to how social role of an art teacher is identified by professional community and society in general. Thus, this proves that if no skilled artist blacksmith was present, the development of the profession and art was hampered for over half a century. Ukrainian situation is unique in this sense, as while there was considerable social demand for the profession (as it was proven by subsequent blacksmithing revival of the 1990s-2000s), the enthusiasts who reinstated blacksmithing education often had no teaching tradition to turn to due to this void period. Lilia Pasichnyk (2017) provides evidence of extermination of the school of artistic blacksmithing.

Instead, very plausible is the assumption of Joseph Hofmarcher (2019) about the huge potential that blacksmithing culture can bring to society. Hofmarcher, a founder and curator of the Symposia Iron Camp (Ybbsitz, Austria), aimed at development of metal design and handicraft in Europe, established a prolific cooperation with the Blacksmith's Festival in Ivano-Frankivsk. This cooperation is a convincing example of socio-cultural component of blacksmithing, when Ukraine is integrated into All-European development of blacksmithing.

As for the periodization of emergence and development of the school of blacksmithing art there is no one established opinion in academic community. Most of the authors, i.e. Volodymyr Mogilevskyi (2012), Ihor Rudenko (200), and Anastasia Varyvonchyk (2020) support the view that development of Ukrainian school of blacksmithing art started in the 1970s.

Such notion that there was not any tradition of blacksmithing art in Ukraine is erroneous. Historical data prove quite the opposite, as the blacksmithing craft existed in Ukraine since the establishment of Kyiv Blacksmithing Guild in 14941497. This initial period of Ukrainian blacksmithing art and craft ended in the first half of the 19th century. The second stage of rapid industrial development of many Ukrainian cities that involved blacksmithing unfolded from the mid-19th century and up to 1917. The third stage when blacksmithing art was exterminated by the Soviet authorities (though blacksmithing as a craft was preserved at a certain level) may be described as a void between 1917 and 1970. The fourth stage of rapid development of blacksmithing as an art started in the 1970s and ended in the early 2000s. The fifth and last stage of stagnation and certain decline has lasted since the early $21^{\text {st }}$ century and up to the present time. 
Blacksmithing craft in the territory of contemporary Ukraine should be considered one of the oldest of existing to this day. "Archaeological expeditions in the Ukrainian lands during the second half of the 19th century prove that the first blacksmiths worked with copper there some five thousand years ago" (Rohotchenko, 2018, p. 97). Archaeological discoveries dating back to the times of Kyivan Rus include ironwork, predominantly household items and instruments: axes, spades, scythes, horseshoes and harnesses, various instruments for carpentry and masonry. Technology of professional metalwork has been known in Ukraine since the 11th century B. C. Blacksmithing craft was a natural trade for the inhabitants of the lands of modern-day Ukraine. The main contributing factor for that is the rich bed of iron ore in the land that enabled smelting-the core component of blacksmithing craft. Practically from the times of Kyivan Rus our domestic blacksmithing should be divided into two trends: craft and art. Active construction of the churches in the cities of Chernihiv, Pskov, Novgorod, Kyiv during the heyday of Kyivan Rus involved blacksmithing guilds: carpenters, bricklayers, masters working with the plinth bricks. Blacksmiths produced complex metal constructions supporting the walls of the new buildings, as well as the metal ladders and staircases, constructions supporting the arch roofs, domes, window bars-all marked with the high level of mastery and use of progressive technologies of welding (Rohotchenko, 2018). It may be stated that almost since the times of Kyivan Rus forges became professional productions, thus, a blacksmith was a key professional in villages and cities. Socio-economically, it meant the start of professional Ukrainian blacksmithing.

"Magdeburg rights granted to Kyiv in 1494-1497 by the grand duke of Lithuania Alexander Jagiellon and confirmed by the Lithuanian dukes in 1516 and 1544 had a considerable impact on formation of the trade guilds in the lands" (Kucherenko, 2006, p. 10). Trade guilds were subordinated to the new city administration-the magistrate. Historical records mention that blacksmiths had to produce a certain number of axes for the governor, like the shoemakers-a certain number of boots. This fact captures the exact date when existence of the blacksmithing profession in the present-day Ukraine was first mentioned is written sources. The characteristic feature of the blacksmithing craft and art in 17th-18th-century Ukraine was strengthening of guild relations. Forges gradually transformed into the mini-factories (in the modern sense of the word).

Further evolution of blacksmithing takes place during the early 19th century. "In the period of 1800s-1820s there existed 15 trade guilds and 56 blacksmithing shops in Kyiv" (Rohotchenko, 2017, p. 69). Life of Kyiv blacksmithing guild for a long time was chronicled by the blacksmiths themselves. The chronicle of the Kyiv Blacksmithing Guild provides a detailed picture of life and work of the blacksmiths from, for instance, 19th century. 
The early 20th century, specifically the year 1902, marked an end of existence for the Kyiv Blacksmithing Guild. According to the archival documents, the Guild payed significant sums in taxes and conducted legal and educational activities. The advent of capitalist relations in Ukraine ruined the traditional patriarchal handicraft structure. Construction boom at the turn of the 20th century acted as a catalyst for development of blacksmithing art. The owners of the forges started their individual businesses. Professional artists were employed for the blacksmithing enterprises. In a short period, since the 1880s and up to the Bolshevik revolution of 1917, Ukrainian blacksmithing produced hundreds of highly artistic metalwork pieces that entered the pages of history of European blacksmithing art. The number of forges went four times higher. This was the last boost for the blacksmithing production and art in the well-developed industrial complex of then-capitalist Ukraine. After 1917, almost all major private enterprises in Ukraine ceased their operation. Village forges and forges at the industrial plants, naturally, still existed, yet the blacksmithing art came to a halt.

"The void in Ukrainian blacksmithing lasted till 1970" (Rohotchenko, 2017, pp. 69). Blacksmithing art in Ukraine was revived in the Kyiv region when a number of artists started their professional careers. For instance, Oleksandr Milovzorov returned to Kyiv after graduating from the Leningrad Vera Mukhina Higher School of Art and Design. That year he met Oleh Stasiuk who worked in the newly opened forge at the open-air museum Pyrogiv. Other artists gradually returned to the forges in different cities and villages across the state. "Blacksmithing spread over Ukraine at an unstoppable pace, bringing more and more blacksmithing cells back to life” (Rohotchenko, 2017, p. 69).

Rapid development of Ukrainian ironwork in general and its Kyiv cell in particular, as well as establishment of the new forges in almost all regions of the country went in parallel to the emergence and development of the modern-day independent Ukraine.

Ukrainian Art historian Ihor Rudenko (2006) states that during the Soviet times, machine-building industry and metallurgy were stuffed with various equipment, including the forging hammers. Industrial forging, unlike metal art, was widely used at the plants and factories for pressing the details of industrial and agricultural equipment. When the Soviet imperial industrial behemoth collapsed in the early 1990s giving way to the economy based on the small selfaccounting enterprises, there was no problem to buy a pneumatic hammer at a price of scrap metal. Thus, across Ukraine, people with some fantasy independently opened small forges. "By the mid-1990s, wrought ironwork, though still low-quality, but nevertheless in sufficient quantity became available for interior and exterior decoration of office buildings and private mansions" (Rudenko, 2006, p. 299). 
In Ukraine, blacksmithing art since the 1980s and up to the 2000s flourished for a number of reasons. One of them is the finally gained freedom to choose the means of conveying an artistic design. Unlike the Baltic states where blacksmithing art actively evolved since the 1960s, Ukrainian artists experienced a number of restrictions. During the 1980s, ceramics and metal art prevailed over the other decorative and applied arts. "Anatoliy Haidamaka and Oleksandr Milovzorov, while communication with the other artists of the Department of Monumental art of the Union of Artists in Kyiv, promoted blacksmithing art at all times” (V. Melnychenko, personal communication, May 10, 2017).

By the early 2000s there started a true "Renaissance" of blacksmithing art in the cities of Ukraine, linked to the metalwork being in fashion, whereas the trade of village blacksmiths was almost lost. Its traditions were maintained mostly by the individual enthusiasts who were amateur blacksmiths. The next 15 years would be the most prolific period in the development of Ukrainian blacksmithing. Dozens of professional festivals, including Ivano-Frankivsk festival and Donetsk festival being the major ones, as well as the group and solo exhibitions, participation of Ukrainian blacksmiths in the international exhibitions and forums, allowed Ukrainian blacksmithing art to reach the European level.

As for the educational process in blacksmithing, for a period of time it failed to progress at the same rate as the blacksmithing art. The issue of professional blacksmithing training has not been sufficiently covered in Ukrainian art history. Rostyslav Shmahalo, a researcher from Lviv, is one of the most prolific promoters of educational process. "Art education as a manifestation of a human creative potency is aimed to become the center of any education. Blacksmithing, enamel art, gem cutting, goldsmithery experienced a revival during that period," writes R. Shmahalo in the foreword to the second volume of his Encyclopedia of Metal Art (Shmahalo, 2015, p. 6).

Professional training in blacksmithing art and craft started in the times of emergence of capitalist relations in Ukraine. In the $19^{\text {th }}$ century, forges transformed into the big shops where blacksmithing neighbored with other kinds of metal processing. They were not just enterprises but the first schools of blacksmithing. "At the shops, there operated the institutions, the structure of which resembled the one of the vocational education. An adult blacksmith had several students assigned to him” (Rohotchenko, 2018, p. 99). The training process took a substantial time (up to ten years).

That is how the 'homegrown' masters received their training. Economic component of development of such enterprises allowed spending significant sums on specialized training of homegrown professionals who were obligated to work at this production in the future. It may be concluded that despite emerging capitalism and market relations, the feudalistic component was still strong, with the training conditions of a student when he could not move to other enterprises 
being a proof for that. Nevertheless, that was the time when the gradual changes started. In the times prior to Bolshevik revolution, blacksmithing training at the powerful industrial productions of Ukraine received a lot of attention. Specialized professional courses existed at the Kyiv docks and at the Kyiv Locomotive and Railcar Repair Plant, as well as at the other sites. The pause in education of artist blacksmithing lasted from 1917 till the late 1980s. However, despite all obstacles, at the present time art education in blacksmithing profession has won a right to life.

Contemporary state of training to become an artist blacksmith generally is unsatisfactory. As of today, there are only a few higher educational institutions providing such training. Primarily, the reason for that is the crisis in economy that has lasted in Ukraine for the recent seven years. Blacksmithing is an applied art that requires large investment. Unlike other kinds and genres of fine art where a student mostly only needs a room to study, a computer, canvas, oils, yarn or clay, a blacksmith needs a furnace, coal, equipment, heavy hammers, a park of various machines, specific premises equipped with powerful air extraction system, painting room, cameras for drying the painted elements or artworks, and many other items and spaces necessary for the production. Also, the price for the metal itself is high, as well as for the electricity and security. All of the above made blacksmithing education an unaffordable burden for the most secondary and higher educational institutions. Many departments that train artists blacksmiths, were either transformed or closed. The process was painful and underwent several stages. At first, the teachers attempted to make painting and creating blacksmithing designs on paper a substitute for the ceased practical training in the forges. As for the jewelry making that caused the situation when no practical skills were gained. For instance, it was the case for the Art Metal Department of the National Academy of Culture and Arts Management: after the closure of the shops, the students were offered to develop 3D-designs of their works. Any real experience both with jewelry making and blacksmithing is gained only through the practical studies. The next important factor that reduced the number of art metal departments to a minimum was very realistic prospect of unemployment for the graduates. That was the worst part of the law of markets. Professional artist blacksmith became unneeded for the industrial production, as it was in the 1990s and early 2000s. Designers of the last decade has learned to make skillful compilations of some else's achievements from the professional catalogs. Thus, the cheap mass production pieces (cast or pressed elements) caused the eventual result: the mass produced pieces were reasonably cheaper.

Lviv National Academy of Arts has been and still is a major art educational institution. The history of founding of the Art Metal Department dates back to the 1989 when the head of the Lviv State Institute of Decorative and Applied Arts (former name of the institution) initiated establishment of the Section of Metal 
Art at the Department of Glass Art. Emmanuil Mysko was a big admirer of blacksmithing. According to his resolution of February 18, 1993, the section was reorganized into the Art Metal Department. The first teachers at the Department were: head of the Department, associate professor S. Moroz (1989-2001), senior lecturer V. Sholomiy (1989-2007), lecturer Ye. Bokhoniuk (1991-1995), assistant professor B. Romanets (1993-2009), assistant professor Pleshakov (1992-2012) who taught metal processing technologies. At the present time, the teachers at the Art Metal Department are: head of the department, Honored Worker of Arts of Ukraine I. Frank; Honored Artist of Ukraine O. Bonkovskyi (Head of the Department in 2001-2004); Honored Artist of Ukraine, assistant professor S. Volskyi; senior lecturer A. Sterniuk; Honored Artist of Ukraine, assistant professor O. Ivasiuta; lecturer S. Rozhkovskyi.

The staff of the department puts significant effort in promoting the metal art. For instance, in 1996, for the first time in the country, the personnel of the Department of Art Metal organized public presentations on blacksmithing performed by the lecturers and students in the central part of the city of Lviv that boosted blacksmithing festival movement in Ukraine. The Art Metal Department of the Lviv National Academy of Arts is a permanent partner of such festivals. Achievements of the teachers and graduates of the Department are a prominent phenomenon in the history of contemporary Ukrainian blacksmithing (Lviv National Academy of Arts, n. d.).

Mykhailo Boychiuk Kyiv Institute of Decorative and Applied Art and Design is one of the oldest art educational institutions in Ukraine. The Department of Ceramics, Decorative Sculpture, Woodworking Art, and Art Metal originated from the experimental workshops founded back in the 1936-as a Department of Ceramic Artworks. In 2014, Department of Ceramics, Decorative Sculpture, Woodworking Art, and Art Metal was established as a result of merging the two departments: Department of Ceramic Arts and Sculpture and Department of Woodworking Art and Art Metal. Since 2010, the Department has the graduate specialization "Art Metal" that includes programs "Jewelry Art" and "Decoration of Arms”.

The students learn blacksmithing, jewelry making, decoration of arms, and are trained to create highly artistic sacred artworks. Mykola Ponomarenko was one of the first teachers at the department. After his passing away, Illya Popiuk became a primary "metal tutor" as he is not only an established artist blacksmith but also authored a number of research works on the history of Ukrainian repoussé and chasing (Mykhailo Boychiuk Kyiv Institute of Decorative and Applied Art and Design, n. d.).

The Transcarpathian Academy of Arts was founded under the Resolution of the Ministry of Education and Science of Ukraine No. 424 of April 13, 2016. Transcarpathian Art Institute was renamed and changed the type of education it 
offers. In its educational activity, the institution trains specialists in several specializations, including 023 "Fine art, decorative art, restoration" (painting, graphics, ceramic art, blacksmithing art, woodworking art, restoration). It should be emphasized that this is the first higher educational institution in Zakarpattia region. It was established in March 1946 under the name Uzhhorod State Art and Industrial School with Adalbert Erdeli, famed painter of the region, as its head. Blacksmithing art has always been a traditional handicraft and professional creative activity in Zakarpattia. The lecturers do their best to train young blacksmiths in accordance with the traditional art of the region (Transcarpathian Academy of Arts, n. d.).

Vasyl Stefanyk Precarpathian National University in Ivano-Frankivsk devotes many efforts to educating the artists blacksmiths. The aim and scope of the course "Metalworking Art" is researching the processes of emergence and development of the metalworking art in Ukraine: studying the main techniques, kinds, and forms of the metal artworks, as well as their functionality and aesthetic features. Vitaliy Horodetskyi teaches art metal at the department.

Ivan Trush Lviv State College of Decorative and Applied Arts has a special place in the history of art education of Ukraine. For the 139 years of its existence, the concept of this art school remained unchanged. The initial aim was to establish an educational institution the program of which would be true to the foundations of the national culture. This center of art education is linked to formation of pedagogical and aesthetic methods of training the talented youth. The students of the college graduate in the following specializations: monumental and decorative painting, monumental and decorative sculpture, fashion design, architectural design, ceramic art, art metal, woodworking art, weaving art, graphic design, artworks' restoration.

The students of the Borys Grinchenko Kyiv University study graduate in specializations that are closely liked to blacksmithing-enamel artist and jewelry artist. The Department of Fine Art of the Art Institute of the Borys Grinchenko Kyiv University was established as a result of reorganizing the Department of Fine Art and Design in 2013-2014. The Department graduates student specializing in "Fine Art." The main aspects of education are: "Art" (with the specialization in "Fine Art," with the list of respective arts). Graduates are awarded the academic degree of BA in Fine Art, with their professional qualification being the "artist." "Jewelry Art" and "Jewelry Designer" are minor specializations. The aim of implementation of "Jewelry Art" into the curriculum is to train the professionals able to create unique, exclusive jewelry pieces and implement their designs from scratch. Jewelry design is a synthetic art that organically combines both the skills in jewelry craft and truly artistic knowledge and skills. Unfortunately, the blacksmithing is not in the list of the specializations provided by the institution (Borys Grinchenko Kyiv University, n. d.). 
Igor Sikorsky Kyiv Polytechnic Institute is one of the oldest higher educational institutions in Ukraine. In 1998, Kyiv Polytechnic Institute celebrated its 100th founding anniversary. In 1994, the dean of the Faculty of Engineering Physics of the Kyiv Polytechnic Institute A. Siomyk initiated establishing the specialization "Art of Metal Casting and Jewelry Casting” at the Department of Foundry Engineering. Thus, traditional training of the foundry engineer now includes new theoretical and practical courses: history of the art of metal casting and basics of art history, metallurgy of precious metals, technology of forming the shape of the molds, metals, alloys, and technologies of the art of metal casting and jewelry casting.

At the Department, a forge opened that was organized by the well-known Kyiv architect and blacksmith Volodymyr Diomin who worked there himself. The forge served as an illustrative example of production of the blacksmithing artwork and prompted many students of the Kyiv Polytechnic Institute to open the enterprises of their own. Unfortunately, as of today, the forge is no longer operational (Igor Sikorsky Kyiv Polytechnic Institute, 2006).

Among the higher vocational schools training blacksmithing professionals, the School No. 5 in the city of Vinnytsia should be highlighted. Adapted to the market conditions, several specialization are united there: sanitary system and equipment fitter, electro-gas welder, and metal art maker. Such method, undoubtedly, is progressive in some sense as the youth gains skills under the supervision of professional educators. Also important are the lectures in general disciplines, including the art history classes.

\section{Conclusions}

General ascent of Ukrainian blacksmithing (in particular, in Kyiv region) at the beginning of the 21st century that entered the art history of Ukraine as the period of "metal art Renaissance" experienced a slowdown since 2010 and up till now. Despite all hardships encountered by Ukraine in the recent years (war, market instability, pandemic that lowered the number of commissions significantly) the blacksmithing trade manages to survive. Sporadically, metal artworks are still presented at the art exhibitions of various levels, though the former glory of blacksmithing art seems to be over for now.

Nevertheless, it would be too soon to proclaim the forcible pause in the development of blacksmithing art to be a full stop. The issue of proper blacksmithing education and training remains one of the most painful problems of the contemporary time. The European state of over 40 million people definitely needs more educational centers that would teach the youth the ancient profession. This, in turn, would give a new impetus to the blacksmithing art so that there 
would be no need for the art historians of the future to invent the term "second revival of Ukrainian blacksmithing."

Presented periodization serves as the best argument allowing to single out blacksmithing art as a highly valuable piece of Ukrainian national identity, as it was one of the first arts, targeted by the Bolsheviks in 1917. The following "void" of 70 years, tirelessly maintained by the Soviet authorities, and eventual heyday of the 1990s-2000s after gaining independence are telling illustrations of suppression and further revival of a key component of national culture. Initially, period of mature socialist realism, turning to blacksmithing was a manifestation of dissent and nonconformity for an artist in Ukraine. After Ukraine gained independence, a number of annual blacksmithing festivals was organized in different regions of the state and options for artist blacksmith's training emerged. Thus, it is clear that there exists both practical and cultural demand for artists blacksmiths in society.

The present findings could be included in the courses on art history in specialized educational institutions, and will be valuable for compiling the textbooks on the history of visual art.

\section{References}

Borys Grinchenko Kyiv University. (n. d.). Istorychna dovidka kafedry [Historical reference of the Department]. https://im.kubg.edu.ua/struktura/2011-06-23-12-44-46/kafedra-obrazo tvorchoho-mystetstva-ta-dyzainu/istorychna-dovidka/283-istorychna-dovidkakafedry.html

Hofmarcher, J. (2019). Iron Camp - New Paradigms for Metaldesign and Handcrafts. In Art Metal. Visions of Future (29-31). Ivano-Frankivsk: Mantykora.

Honchar, K. (2013). Tradytsii ta novatsii u suchasnomu dekoratyvno-prykladnomu mystetstvi [Traditions and innovations in contemporary decorative and applied arts]. Mystetstvoznavstvo Ukrainy, 13, 62-68.

Igor Sikorsky Kyiv Polytechnic Institute. (2006). Khudozhnie lytvo Kyivskoho politekhnichnoho [The art of metal casting at the Kyiv Polytechnic Institute]. Retrieved from https://kpi.ua/633-7

Kucherenko, V. (2006). Kyyivskomu kovalskomu tsekhu-600 rokiv [The 600th founding anniversary of the Kyiv Blacksmithing Guild]. Kovalska maysternya: dialoh-styl-metal, 1(3), 10-15.

Luts, S. (2013). Formation features of the Classical jewelry House "Lobortas". The Newsletter of Transcarpathian Institute of Arts, 4, 162-169.

Lviv National Academy of Arts. (n. d.). Art Metal department: About. Retrieved from https://nnam.edu.ua/en/faculties/decorative-and-applied-arts//about-403.html

Mogilevskyi, V. (2012). Khudozhnii metal Kyieva [Art metal of Kyiv]. Kyiv: Kovalska Maisternia.

Mykhailo Boychiuk Kyiv Institute of Decorative and Applied Art and Design. (n. d.). Kolektyv kafedry khudozhnoi keramiky, dekoratyvnoi skulptury, dereva ta metalu [Staff of the Department of Ceramic Arts and Sculpture and Department of Woodworking Art and Art Metal]. Retrieved from https://kdidpmid.edu.ua/academy/fakultety/fakultet-deko 
ratyvno-prykladnogo-mystecztva/kafedra-hudozhnoyi-keramiky-dekoratyvnoyiskulptury-dereva-ta-metalu/kolektyv-kafedry-hudozhnoyi-keramiky-dekoratyvnoyiskulptury-dereva-ta-metalu/

Pasichnyk, L. (2017). Yuvelirne mystetstvo Ukrainy XX-XXI stolit [Jewelry making art of Ukraine of 20th-21st centuries]. Kyiv: Naukova dumka.

Rohotchenko, S. (2017). Istorychni shliakhy rozvytku khudozhnoho kovalstva naprykintsi 20 ta pochatku 21 storichchia (Do istorii rozvytku suchasnoho kovalskoho mystetstva Ukrainy) [Historical paths of development of blacksmithing art at the end of the $20^{\text {th }}$ and in the early $21^{\text {st }}$ centuries]. Visnyk Kharkivskoi derzhavnoi akademii dyzainu i mystetstv: Zbirnyk naukovykh prats, 4, 66-70.

Rohotchenko, S. (2018). Deiaki istoryko-mystetski aspekty stanovlennia ukrainskoho kovalstva [On some historical and art aspects of development of Ukrainian blacksmithing]. Tradytsii ta novatsii u vyshchii arkhitekturno-khudozhnii osviti, 2, 93-101.

Rudenko, I. (2006). Khudozhestvennaia kovka [Art Metal]. MIST (mystetstvo, istoriia, suchasnist, teoriia), 3, 298-307.

Shmahalo, R. (2015). Entsyklopediia khudozhnoho metalu [Encyclopedia of Art Metal], vol. 2. Khudozhnii metal Ukrainy XX-XXI st. [Metal Art of Ukraine of the 20th-21st centuries]. Lviv: Apriori.

Smyrna, L. (2017). Stolittia nonkonformizmu v ukrainskomu vizualnomu mystetstvi [A century of nonconformism in Ukrainian visual art]. Kyiv: Feniks.

Transcarpatian Academy of Arts. (n. d.). Historical background on Transcarpathian art education. Retrieved from http://artedu.uz.ua/zam_eng.html

Varyvonchyk, A. (2020). Khudozhni promysly Ukrainy: geneza, istorychna evoliutsiia, suchasnyi stan ta tendentsii [Ukrainian handicrafts: genesis, historical evolution, contemporary situation and tendencies]. Kyiv: Lira-K.

Zuziak, T. (2017). Stanovlennia y rozvytok pedahohichnoi osvity na Podilli (kinets 18 pochatok 20 stolittia) [Emergence and development of pedagogical education in Podillia region (in the late 18th and through the early 20th century)]. Vinnytsia: Nilan-LTD. 